\title{
The Effects of Growth Hormone and Sex Steroid on Lean Body Mass, Fat Mass, Muscle Strength, Cardiovascular Endurance and Adverse Events in Healthy Elderly Women and Men
}

\author{
S. Mitchell Harman ${ }^{a}$ Marc R. Blackman ${ }^{b}$ \\ alntramural Research Program, National Institute on Aging, National Institutes of Health, and \\ bDivision of Endocrinology, Department of Internal Medicine, Johns Hopkins University School of Medicine, \\ Baltimore, Md., USA
}

\section{Key Words}

Growth hormone $\cdot$ Testosterone $\cdot$ Oestrogen $\cdot$ Sex

hormones · Elderly population · Lean body mass · Fat mass · Adverse events

\begin{abstract}
Decreases in growth hormone $(\mathrm{GH})$ and insulin-like growth factor I occur with age, in addition to oestrogen deficiency in women and a reduction in the levels of testosterone in men. These age-related hormonal changes may contribute to reductions in lean body mass, muscle strength and cardiac endurance, which can be partially reversed in elderly people with $\mathrm{GH}$ treatment, and testosterone supplements and oestrogen/progestin hormone replacement therapy in men and women, respectively. These treatments are, however, thought to have potentially serious adverse effects. We conducted a study to evaluate the separate and interactive effects of $\mathrm{GH}$ and sex steroids on body composition, muscle strength and cardiac endurance as well as the rate of adverse events in healthy elderly people. The results of the study
\end{abstract}

A full report of these data appears in Blackman MR et al: JAMA 2002;288:2282-2292.

\begin{tabular}{ll}
\hline KARGER & ( ) 2003 S. Karger AG, Basel \\
0301-0163/03/0607-0121\$19.50/0 \\
$\begin{array}{l}\text { Fax +41 61 306 1234 } \\
\begin{array}{l}\text { E-Mail karger@karger.ch } \\
\text { www.karger.com }\end{array}\end{array}$ & $\begin{array}{l}\text { Accessible online at: } \\
\text { www.karger.com/hre }\end{array}$
\end{tabular}

showed that although there were beneficial effects with $\mathrm{GH}$ and sex steroid treatment, a high percentage of adverse effects occurred after 26 weeks of treatment, demonstrating a need for more research on the safety of hormonal therapy in the elderly population.

Copyright $@ 2003$ S. Karger AG, Basel

\section{Introduction}

Decreases in growth hormone $(\mathrm{GH})$ and circulating insulin-like growth factor I (IGF-I), oestrogen deficiency in women and diminished levels of testosterone in men occur during human ageing [1-3]. Evidence to date is consistent with the hypothesis that these age-related decreases in hormone balance and regulation contribute to the concomitant reductions in lean body mass (LBM), muscle strength and cardiac endurance, and increases in body fat observed with normal ageing [4-6]. The treatment of non-elderly GH-deficient adults with recombinant human $\mathrm{GH}$ (rhGH), hypogonadal men with testosterone and hypogonadal women with oestrogen/progestin hormone replacement therapy (HRT) can reverse or attenuate similar changes in body composition and function which are seen in these patients $[7,8]$.

Dr. S.M. Harman

Kronos Longevity Research Institute

2222 E. Highland, Suite 220

Phoenix, AZ 85016 (USA)

Tel. +1 602778 7484, Fax +1 602778 7485, E-Mail Harman@kronosinstitute.org 
Several reports indicating that $\mathrm{rhGH}$ or testosterone supplementation increases LBM and reduces body fat in elderly men have led to public interest in the use of rhGH to delay these (and other) effects of ageing [9-11]. The efficacy of these hormone interventions (either alone or in combination) to improve physiological and functional outcome measures remains uncertain. Moreover, GH treatment in adults, especially older adults, may be accompanied by adverse reactions such as carpal tunnel syndrome, fluid retention with peripheral oedema, joint pain and swelling, gynaecomastia, glucose intolerance and, possibly, increased risk of cancer [12-15]. Testosterone supplementation could potentially accelerate the growth of prostate cancer or hyperplasia, and there is concern regarding whether the effect of testosterone on the plasma lipid profile (lower high-density lipoprotein and/or increased low-density lipoprotein cholesterol) might promote the development of atherosclerosis. Even HRT in women has recently been called into question because of recent studies showing a lack of benefit for, and in some cases an increased risk of, cardiovascular disease and a greater risk of breast cancer [16]. The marketing of rhGH and other hormone supplements to lay persons often ignores the extent to which these adverse events may occur.

\section{Study Design and Methods}

We evaluated the separate and interactive effects of administration of rhGH and sex steroids on body composition, muscle strength and cardiac endurance. We also determined the rates of occurrence of adverse events during treatment in healthy, ambulatory, community-dwelling women $(\mathrm{n}=57)$ and men $(\mathrm{n}=74)$, aged between 65 and 88 years. The randomized, double-masked, placebocontrolled, non-crossover 26-week trial consisted of the following groups: rhGH (GH group), combined oestrogen/progestin (HRT group [women]), testosterone ( $\mathrm{T}$ group [men]), rhGH plus sex steroid(s) $(\mathrm{GH}+\mathrm{HRT}$ or $\mathrm{GH}+\mathrm{T}$ ) or placebo only (placebo group). We performed serial evaluations of serum levels of IGF-I, oestradiol (women only), testosterone (men only), and baseline and 26-week assessments of LBM and total fat mass by dualenergy X-ray absorptiometry, total muscle strength by isotonic 1-repetition maximum testing, and aerobic capacity by measurement of $\mathrm{VO}_{2}$ max during graded treadmill exercise tests. Adverse effects were assessed at regular intervals using structured questionnaires, physical examination and laboratory tests, including measurements of haematocrit, blood glucose and hormones. Six individuals (four women, two men) withdrew from the study before completing the full 26 weeks of treatment. Results of intent-to-treat analyses by analysis of variance in all participants randomized are reported below.

\section{Results}

In women, mean IGF-I levels rose after 26 weeks of treatment with GH $(\mathrm{p} \leq 0.001)$ or GH + HRT $(\mathrm{p} \leq 0.05)$, with no significant difference between those receiving $\mathrm{GH}$ alone and $\mathrm{GH}+\mathrm{HRT}$. In men, administration of $\mathrm{GH}$ or $\mathrm{GH}+\mathrm{T}$ increased IGF-I levels $(\mathrm{p}=0.0001)$ with no differences observed between the latter treatments. Administration of GH elicited a greater increase in IGF-I levels in men compared with women ( $\mathrm{p} \leq 0.01)$. Administration of sex hormone(s) alone or with GH led to similar increases in serum oestradiol levels in women $(\mathrm{p} \leq$ $0.0001)$ and in serum testosterone levels in men ( $p \leq$ 0.0005).

As shown in figure 1a, LBM in men increased after administration of $\mathrm{GH}(\mathrm{p}<0.0001)$ and $\mathrm{GH}+\mathrm{T}(\mathrm{p}<$ 0.0001 ), but the increase did not reach significance with testosterone alone $(p=0.06)$. There was a greater increase in LBM after $\mathrm{GH}+\mathrm{T}$ compared with $\mathrm{GH}$ alone $(\mathrm{p}<$ 0.001). In women, total LBM increased after administration of GH $(\mathrm{p}<0.001)$ and GH + HRT $(\mathrm{p}<0.0001)$, but not with HRT alone. Changes in LBM in the $\mathrm{GH}$ and $\mathrm{GH}$ + HRT groups did not differ from each other (fig. 1b). In men, fat mass decreased after administration of GH ( $p<$ $0.0001)$, and $\mathrm{GH}+\mathrm{T}(\mathrm{p}<0.0001)$, but not with testosterone alone (fig. 1c). The fat mass decrease after administration of $\mathrm{GH}+\mathrm{T}$ was greater $(\mathrm{p}<0.001)$ than that after treatment with $\mathrm{GH}$ alone. In women, total fat mass decreased to a similar extent $(\mathrm{p}<0.001)$ after administration of GH or GH + HRT, but not with HRT alone (fig. 1d). The only significant change in total body strength in men was a $6.8 \%$ increase in the $\mathrm{GH}+\mathrm{T}$ group $(p<0.05)$. Strength did not change significantly in any female treatment group. In men, $\mathrm{VO}_{2}$ max increased by $8.5 \%$ in the $\mathrm{GH}+\mathrm{T}$ group $(\mathrm{p}<0.001)$, whereas in women, $\mathrm{VO}_{2} \mathrm{max} / \mathrm{kg}$ body weight did not increase significantly in any treatment group. Changes in LBM were positively and exponentially related to changes in total body strength $(\mathrm{r}=0.255, \mathrm{p}<0.005)$ and in $\mathrm{VO}_{2} \max (\mathrm{r}=0.324$, $\mathrm{p}<0.001)$.

Significant incidences of oedema and arthralgias occurred in GH-treated women $(\mathrm{p}<0.05)$, carpal tunnel symptoms were common in the $\mathrm{GH}+\mathrm{T}$ group $(\mathrm{p}<0.05)$ 
Fig. 1. Percentage changes in body composition variables in men (left) and women (right) after 26 weeks of hormone or placebo treatment. Bars have error bars at 1 standard deviation and $p$ values vs placebo are shown above or below each bar. a Significant increases in LBM in men treated with GH and $\mathrm{GH}+\mathrm{T}$. b Significant increases in LBM in women treated with $\mathrm{GH}$ and $\mathrm{GH}+\mathrm{HRT}$. c Significant decreases in body fat mass in men treated with GH and GH + T. d Significant decreases in body fat mass in women treated with $\mathrm{GH}$ and $\mathrm{GH}+\mathrm{HRT}$.
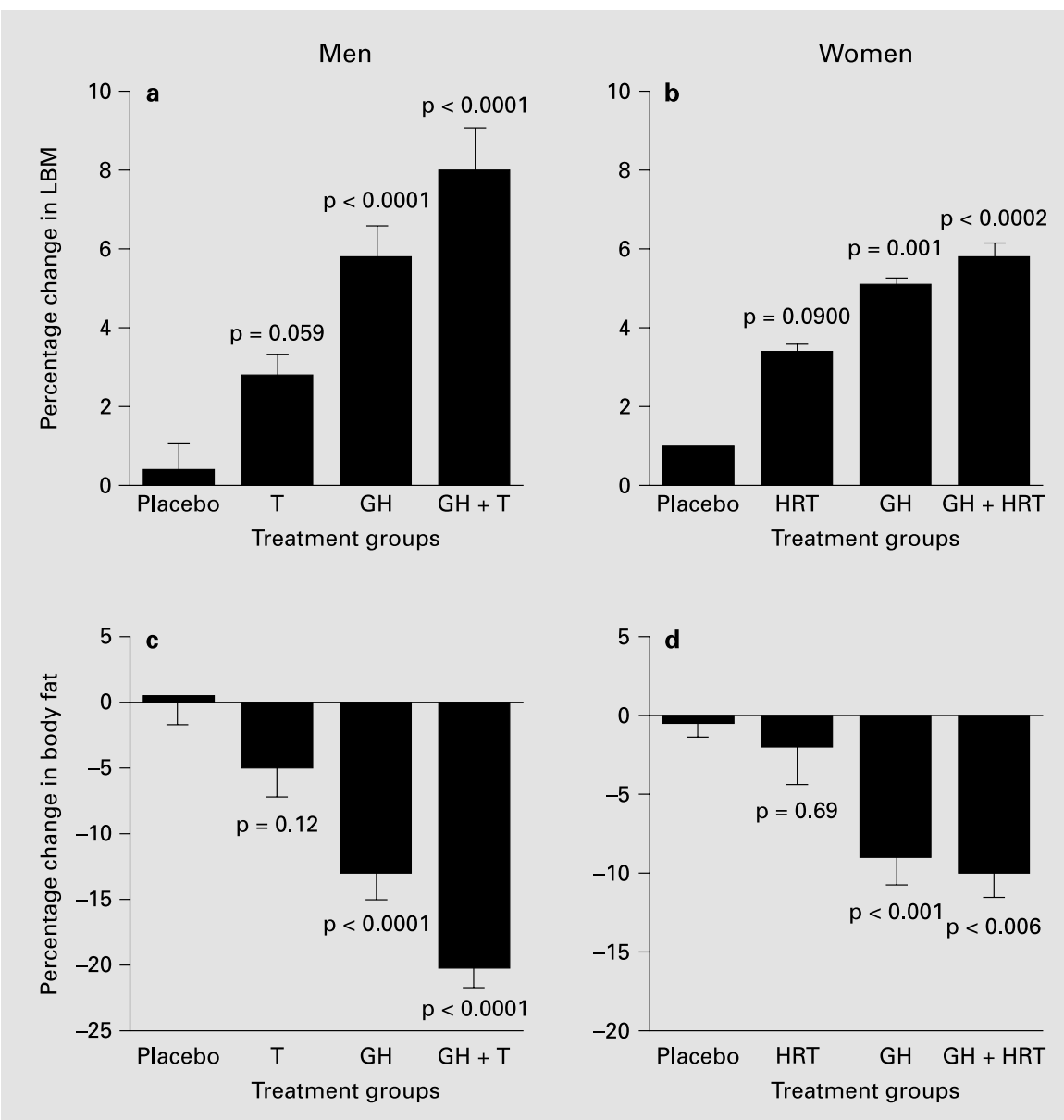

and arthralgias were a significant complaint in GHtreated men $(p<0.01)$. Symptoms of oedema and carpal tunnel syndrome occurred at substantial, but non-significant, rates in women in the HRT group. Mean serum IGF-I level was correlated $(\mathrm{p}<0.05)$ with the total number of GH-related adverse effects. No changes in body weight or blood pressure were observed. In women, the rate of new-onset glucose intolerance was non-significant and diabetes mellitus did not occur, whereas six men developed diabetes, five of whom were receiving $\mathrm{GH}$ or $\mathrm{GH}+\mathrm{T}(\mathrm{p}<0.05)$. At 26 weeks, serum glucose levels sampled following fasting, and at the 120-min time-point of a glucose tolerance test, showed significant increases compared with baseline tests in both men and women receiving rhGH. There were no significant increases in mean haematocrit values compared with placebo and no male participant had haematocrit values greater than 55\% (i.e. polycythemia). Mean serum prostate-specific antigen [PSA] levels decreased in the GH-treated men $(p<0.01)$ and were unchanged in the other groups, but two men in the testosterone group had increases in PSA of more than $1.0 \mathrm{ng} / \mathrm{dl}$. Prostate symptom scores did not increase. Approximately $85 \%$ of the participants with GH-related adverse effects experienced relief after a $25 \% \mathrm{GH}$ dose reduction. This study was too small and too short in duration to assess the effects of hormone treatments on the development of cancer or cardiovascular disease.

\section{Discussion and Conclusion}

Our findings suggest that GH and sex steroid supplementation, when given in combination to a carefully selected group of healthy elderly men and women, exert potentially beneficial effects on physiologically important outcome measures, such as body composition, and that an additive effect of $\mathrm{GH}$ and testosterone in men can improve muscle strength or aerobic capacity. Caution is war- 
ranted, however, as a variety of adverse effects occurred in a high percentage of people after 26 weeks of doses of rhGH and testosterone or oestrogen, even though only physiological increases in serum IGF-I, testosterone or oestradiol were observed. Taken together, our data support the rationale for further investigations of the potential efficacy, safety and overall clinical utility of physiolog- ical and targeted hormone-replacement paradigms in selected healthy and frail aged populations. Until more research, using a variety of treatment paradigms, has defined risk:benefit ratios better, however, the treatment of elderly men and women with rhGH should be confined to well-controlled research studies.

\section{References}

1 Corpas E, Harman SM, Blackman MR: Human growth hormone and human aging. Endocr Rev 1993;14:20-39.

2 Miller MM, Franklin KB: Theoretical basis for the benefit of postmenopausal estrogen substitution. Exp Gerontol 1999;34:587-604.

3 Harman SM, Metter EJ, Tobin JD, Pearson J, Blackman MR: Longitudinal effects of aging on serum total and free testosterone levels in healthy men. Baltimore Longitudinal Study of Aging. J Clin Endocrinol Metab 2001;86:724731.

4 Roy TA, Blackman MR, Harman SM, Tobin JD, Schrager M, Metter EJ: Interrelationships of serum testosterone and free testosterone index with FFM and strength in aging men. Am J Physiol Endocrinol Metab 2002;283:E284E294.

5 Riggs BL, Melton LJ 3rd: Involutional osteoporosis. N Engl J Med 1986;314:1676-1686.

6 Shimokata H, Andres R, Coon PJ, Elahi D, Muller DC, Tobin JD: Studies in the distribution of body fat. II. Longitudinal effects of change in weight. Int J Obes 1989;13:455464.
7 Johannsson G, Rosen T, Bosaeus I, Sjostrom L, Bengtsson BA: Two years of growth hormone $(\mathrm{GH})$ treatment increases bone mineral content and density in hypopituitary patients with adult-onset GH deficiency. J Clin Endocrinol Metab 1996;81:2865-2873.

8 Johannsson G, Grimby G, Sunnerhagen KS, Bengtsson B-A: Two years of growth hormone $(\mathrm{GH})$ treatment increase isometric and isokinetic muscle strength in $\mathrm{GH}$-deficient adults. $\mathrm{J}$ Clin Endocrinol Metab 1997;82:2877-2884.

9 Rudman D, Feller AG, Nagraj HS, Gergans GA, Lalitha PY, Goldberg AF, Schlenker RA, Cohn L, Rudman IW, Mattson DE: Effects of human growth hormone in men over 60 years old. N Engl J Med 1990;323:1-6.

10 Marcus R, Butterfield G, Holloway L, Gilliland L, Baylink DJ, Hintz RL, Sherman BM: Effects of short term administration of recombinant human growth hormone to elderly people. J Clin Endocrinol Metab 1990;70:519-527.

11 Holloway L, Butterfield G, Hintz RL, Gesundheit N, Marcus R: Effects of recombinant human growth hormone on metabolic indices, body composition, and bone turnover in healthy elderly women. J Clin Endocrinol Metab 1994;79:470-479.

12 Cohn L, Feller AG, Draper MW, Rudman IW, Rudman D: Carpal tunnel syndrome and gynaecomastia during growth hormone treatment of elderly men with low circulating IGF-I concentrations. Clin Endocrinol (Oxf) 1993;39: $417-425$.
13 Chipman JJ, Attanasio AF, Birkett MA, Bates PC, Webb S, Lamberts SW: The safety profile of $\mathrm{GH}$ replacement therapy in adults. Clin Endocrinol (Oxf) 1997;46:473-481.

14 Abs R, Bengtsson BA, Hernberg-Stahl E, Monson JP, Tauber JP, Wilton P, Wuster C: GH replacement in 1034 growth hormone deficient hypopituitary adults: demographic and clinical characteristics, dosing and safety. Clin Endocrinol (Oxf) 1999;50:703-713.

15 Holly JM, Gunnell DJ, Davey Smith G: Growth hormone, IGF-I and cancer. Less intervention to avoid cancer? More intervention to prevent cancer? J Endocrinol 1999;162:321330.

16 Rossouw JE, Anderson GL, Prentice RL, LaCroix AZ, Kooperberg C, Stefanick ML, Jackson RD, Beresford SAA, Howard BV, Johnson $\mathrm{KC}$, Morley KJ, Ockene J, et al: Risks and benefits of estrogen plus progestin in healthy postmenopausal women: principal results. From the Women's Health Initiative randomized controlled trial. JAMA 2002;288:321-333. 